\title{
A militarização da política ou a politização das forças armadas? O Oficialato Novohispano e Mexicano, 1810-1822*
}

\author{
The Militarization of Politics or the Politicization \\ of the Military? The Novohispano and Mexican \\ Officer Corps, 1810-1822
}

Christon I. Archer**

\begin{abstract}
Resumo: Os oficiais realistas que lideraram a campanha contra a insurgência patriota na Nova Espanha durante a década de 1810 adquiriram significativa experiência administrativa e política ao mobilizarem recursos locais em prol de sua causa realista. Dessa experiência de governança virtualmente autônoma, os primeiros oficiais realistas moveram-se facilmente para a política nacional após a Independência. A carreira política e militar de Augustín Iturbide é exemplo desta transformação que evidencia que não havia qualquer militarização da sociedade ou da política após a Independência. Os militares que entraram para a política o fizeram como políticos, não como representantes do exército.
\end{abstract}

Palavras-chave: Independência do México, Augustín Iturbide, Insurgência, Exército Novohispano

\begin{abstract}
The royalist officers who led the campaign against the patriot insurgency in New Spain during the 1810s gained a great deal of administrative and political experience as they mobilized local resources in the royalist cause. From this experience of often virtually autonomous local governance, former royalist officers moved easily into national politics after independence. The political and military career of Augustín Iturbide exemplifies this transformation which underscores that there was no militarization of society or politics after independence. Military men who entered politics did so as politicians, not as representatives of the army.
\end{abstract}

Keywords: Independence of Mexico, Augustín Iturbide, Insurgency, Army of New Spain

\footnotetext{
* Tradução de Kellen Baumann. Versão resumida pelo autor de "The Militarization of Politics or the Politicization of the Military?" The Novohipano and Mexican Officer Corps, 1810-1830. In: Jaime E. Rodríguez O. (org.). The Divine Charter: Constitutionalism and Liberalism in Nineteenth-Century México. Lanham: Rowman \& Littlefield, 2005, 205-34. ** Professor Emérito da University of Calgary.
} 
Soldados ¿Qué furor os agita? ¿qué negro velo se extiende delante vuestros ojos? ¿no ves ya en la continuación de vuestro delirio los campos de Anáhuac empapados en vuestra sangre, y nuestros cadáveres nadando en las lágrimas de nuestras desconsoladas mujeres, de nuestros hijos miserables? ¡Ea, soldados! Un instante solo de cordura, una mirada de compasión hacia vosotros mismos; vuestras familias y vuestros amigos os harán abandonar esa bandera oscura, que no es otra cosa que la nube próxima a expedir el rayo de la desolación y el extermino: corred á mis brazos, formemos una misma familia, dad a la patria un día de gloria, y borre el arrepentimiento los de duelo que le ocasionará vuestro extravío. Agustín I es nuestro padre, nuestro libertador: su devisa es amor, humanidad, filantropía. ... ${ }^{1}$ (General José Antonio Echáverri, Jalapa, 6 de diciembre de 1822).

Que hipérbole! Que paixão! Marechal de Campo José Antonio Echáverri tocou os soldados de seu exército em Veracruz com poderosas palavras direcionadas a voltá-los contra seu antigo companheiro do exército monarquista, Brigadeiro-General Antonio López de Santa Anna. Encobrindo os ressentimentos acumulados entre o caçador e a caça, Santa Anna aparentemente formou uma aliança com seu antigo adversário de guerra e republicano, General Guadalupe Victoria. Outros relataram que Santa Anna esteve se comunicando com alguns dos cabecillas dos bandos republicanos, que infestavam o território interno de Veracruz até Puebla. ${ }^{2} \mathrm{O}$ problema maior em Veracruz foi o fato de que os espanhóis continuavam ocupando o castelo de San Juan de Ulúa, o qual guardava a cidade portuária. A partir desta fortaleza, eles ameaçaram uma invasão para restaurar o rei Fernando VII, ocasionalmente, invadindo ou bombardeando a cidade e se envolvendo em muitas intrigas. No lado mexicano, houve muita frustração pela indisponibilidade de armas pesadas para bombardear a fortaleza até a submissão. Santa Anna propôs muitas soluções de assaltos a esquemas bizarros para enganar os defensores espanhóis, mas nada funcionou. Com o porto bloqueado e o comércio sofrendo, mercadores e líderes civis incitaram o exército a prosseguir com seu trabalho. Na Cidade do

1 Proclamação do Capitán General de Veracruz, José Antonio de Echáverri, Jalapa, 6 de dezembro de 1822. In: José María Bocanegra, Memorias para la historia de México independiente, 1822-1846, I. México: Fondo de Cultura Económica, 1987, 167-68.

2 Lucas Alamán, Historia de México desde los primeros movimientos que prepararon su independencia en el año de 1808 hasta la época presente, V. México: J. Mario Lara, 1852, $686 \mathrm{p}$. 
México, o Imperador Agustín de Iturbide perdeu a confiança em Santa Anna e enviou Echáverri para fazer o trabalho.

O imperador viajou para Jalapa, onde se encontrou com Santa Anna e tentou levá-lo à Cidade do México para assumir um novo cargo; em seguida, demitiu-o do comando em Veracruz. Não querendo ser retirado da sua base de poder, Santa Anna retornou ao porto de péssimo humor. ${ }^{3}$ Ele chamou seu regimento e alarmou seus soldados e, particularmente, denunciou a dissolução do Congresso pelo Imperador Iturbide, a qual via como duro golpe à nação mexicana. Com Guadalupe Victoria e outros republicanos ao seu lado, ele falou sobre o crescimento do apoio em muitas províncias à mudança pela forma republicana de governo. Em 06 de dezembro, Santa Anna proclamou o Plano de Veracruz um programa desenhado para forçar Iturbide a reinstituir o Congresso como um primeiro passo e, em seguida, permitir aos seus membros o debate sobre a forma exata de governo - monarquia ou república. Nettie L. Benson descreveu o Plano de dezessete artigos e vinte e dois artigos explicativos como um "documento desorganizado e prolixo", contendo porções do Plano de Iguala e outras proclamações. ${ }^{4}$ Não houve referência ao estabelecimento de uma república, mas a presença dos republicanos e o tom geral das recentes ações de Santa Anna trouxeram algumas sugestões sobre possíveis direções futuras. ${ }^{5}$ Aparentemente, Miguel de Santa María, o ministro Colombiano para o México e natural de Veracruz, elaborou o documento com colaboração de outros civis. Eles sabiam que Santa Anna se opunha ao Imperador e o convenceram a proclamar o Plano. ${ }^{6}$

Embora o Plano de Veracruz não pretendesse abertamente derrubar o Império Mexicano e Agustín de Iturbide, as atividades da Santa Anna convenceram seus oponentes de que tinha tais projetos em mente. $\mathrm{O}$ Marechal de Campo Echáverri fulminou:

Este Santa Anna, que agora prega a república, nunca teve as virtudes de um republicano; vaidoso, pretensioso, arrogante, depredador dos direitos do homem, ingovernável, inimigo da sociedade, bajulador em suas pretensões, baixo em seus procedimentos, ele não tem nenhum outro sistema, nem é animado por outros desejos que não o de dominar os miseráveis. ${ }^{7}$

3 Alamán, [1852], V, p. 678.

4 Nettie Lee Benson. The Provincial Deputation in Mexico: Harbinger of Provincial Autonomy, Independence, and Freedom. Austin: University of Texas Press, 1992, 64p.

5 Alfredo Avila Rueda. Para la libertad: Los republicanos en tiempos del imperio, 1821-23. Tese de Doutorado, Universidad Nacional Autónoma de México, 2001, 244-45.

6 Benson, 1994, p. 64

7 Proclama del Capitán General de Veracruz, José Antonio de Echáverri, 6 de dezembro de 1822. In: Bocanegra. 1987, I, p. 169. 
Santa Anna rugiu de volta: "Viva a nação, viva o congresso livre e soberano, e viva a verdadeira liberdade da pátria, sem jamais admitir ou reconhecer as ordens de Don Agustín de Iturbide!"8 Echáverri sitiou as forças de Santa Anna e Guadalupe Victoria. Santa Anna defendeu a cidade portuária de forma eficaz e ainda conseguiu obter alguns suprimentos da Espanha em San Juan de Ulúa. A artilharia leve disponível à força de sítio de Echáverri, de aproximadamente apenas 3.000 soldados, falhou em quebrar, mesmo as fracas, as muralhas da cidade. No mortificante calor tropical, os soldados não-aclimatados das montanhas, sofreram com a falta de provisões e barracas adequadas. ${ }^{9}$ A velha maldição do vomito negro apareceu para corroer os sitiantes e para lançar o medo nos corações de seus companheiros.

Embora as forças leais a Iturbide tenham conseguido esmagar as revoltas espalhadas, inspiradas pelo Plano de Veracruz em outras localidades do México, a cidade portuária provou ser o objetivo mais difícil. O imperador, que falhou em compreender por que Echávarri não pode completar sua missão, pressionou seu comandante por resultados. No entanto, Echáverri, que havia tão recentemente condenado Santa Anna como traidor, agora aparentemente tomava a questão em suas próprias mãos. No que estava para ocorrer, Lucas Alamán viu a mão das lojas maçônicas, que apenas recentemente haviam recrutado Echáverri e muitos dos seus oficiais. Oprimido pelo medo do fracasso e pela perda da honra militar, Alamán descreveu o processo no qual esses oficiais do exército - novos maçons - caíram sob o controle dos "superiores ocultos". ${ }^{10}$ Em 01 de fevereiro de 1823, Echáverri e seus oficiais assinaram o Plano de Casa Mata, que recomendou a restauração do congresso dissolvido pelo imperador e reconheceu o poder político das províncias. O Plano implementou uma Junta de Províncias, o que apontava diretamente a formação de um sistema federativo. Embora o exército tenha insistido que o Plano não era direcionado contra o imperador, Alamán insistiu que os seus conceitos forneceram aos inimigos de Iturbide, incluindo maçons, alguns deputados retornados das Cortes espanholas, membros cativos do congresso anterior, e muitos outros, a munição que eles precisavam para agir. ${ }^{11}$ Santa Anna e os seus oficiais aderiram ao Plano, e muitas outras guarnições e unidades

\footnotetext{
8 Proclamação de D. Antonio López de Santa Anna e D. Guadalupe Victoria, Cuartel General en Casa Mata, Veracruz, 1 de fevereiro de 1823. In: Bocanegra, 1987, I, p. 191.

9 Alamán, [1852], V, p. 707-708.

${ }^{10}$ Alamán, [1852], V, p. 709.

${ }^{11}$ Alamán, [1852], V, p. 711-713.
} 
do exército o seguiram rapidamente. Nos termos do Plano, o exército sitiante de Echáverri retirou-se para as cidades montanhosas de Jalapa, Córdoba e Orizaba.

O fato de o Plano ter circulado quase que imediatamente para a cidade de Veracruz e para todas as províncias no país ilustrava o ponto de Alamán que poderosas forças políticas e organizadoras bem além do exército deram ao Plano a sua bênção e o pleno apoio. Nesse momento, as lojas maçônicas e os líderes políticos, como Miguel Ramos Arizpe, José Mariano Michelena e outros poderosos políticos civis aparentemente fizeram dos comandantes de exército apenas um pouco mais do que mensageiros, e não os autores intelectuais do programa ${ }^{12}$. A experiência com a monarquia e o imperador Iturbide quase seguiu este curso. Conforme Jaime E. Rodríguez argumentou, o Plano de Casa Mata obteve amplo apoio popular, porque concedeu a autoridade local as representações provinciais. ${ }^{13}$ Seja antimonárquica ou pró-republicana, no entanto, a política do choque pós-colonial agora devorava um libertador, primeiro para o exílio na Itália e, pouco depois, para enfrentar o pelotão militar de fuzilamento em Padilla, Tamaulipas. ${ }^{14}$

A década da Guerra da Independência (1810-1821), uma guerra civil e um cataclísmico conflito entre guerrilheiros insurgentes e contrainsurgentes, foi um destruidor refinado de pessoas, propriedades, e de sistemas. Para o México, foi uma forma de autocanibalismo político e social, que consumiu talento humano, riqueza e civilidade. A nova nação do México sofreu um difícil nascimento, marcado por conflitos - sociais, econômicos, políticos e raciais - complexos e multifacetados, que não podem ser resolvidos simplesmente por proclamações, planos, ou pela independência política da Espanha. ${ }^{15} \mathrm{E}$ devido ao específico final da Guerra em 1821, sob o Plano de Iguala, líderes políticos, incluindo comandantes de exército que lutaram em ambos os lados, enfrentaram a perspectiva de pôr de lado suas inimizades entrincheiradas

12 Benson, 1992, p. 65. ii

13 Jaime E. Rodríguez O. “'Ningun pueblo es superior a otro': Oaxaca y el federalismo mexicano". In: Brian Connaughton (org.). Poder y legitimidad en México, siglo xix. Instituciones y cultura política Mexico: Universidad Autónoma Metropolitana, Iztapalapa \& Miguel Angel Porrúa, 2003.

${ }^{14}$ Ver Lucas Alamán. Historia de Méjico, V, 797-802; William Spence Robertson, Iturbide of Mexico. Durham: Duke University Press, 1952, 294-297; e Timothy E. Anna, The Mexican Empire of Iturbide. Lincoln: University of Nebraska Press, 1990, 233-235.

15 Jaime E. Rodríguez O. "Down from Colonialism: Mexico's Nineteenth-Century Crisis". In: Jaime E. Rodríguez O. (org.). The Mexican and Mexican American Experience in the $19^{\text {th }}$ Century. Tempe: Bilingual Press, 1989, 7-23; 103-106. 
e contemplaram as enormes complexidades da construção ao invés de destruição. Em alguns aspectos, o compromisso de paz de 1821 representou a exaustão dos beligerantes - particularmente da devanescente máquina monarquista contra-insurgente - ao invés de uma vitória ou derrota definitiva. ${ }^{16}$

A nova nação do México emergiu com dois grupos políticos heterogêneos, cada qual reivindicando a vitória - um lado monarquista, transformado, mas mais ou menos intacto e tendente ao centralismo; e lado provincial, mais disforme, potencialmente poderoso, porém desunido, o qual incluía antigos insurgentes e muitas pessoas que pretendiam proteger os direitos e os privilégios locais e provinciais. ${ }^{17}$ Antigos funcionários do exército monarquista, burocratas, clérigos, comerciantes, mineiros e outros criollos dos centros urbanos mantiveram profundas suspeitas acerca dos intelectuais revolucionários insurgentes e seus seguidores em diferentes setores plebeus. Com o impacto da reorientação social e econômica do país durante a década de guerra brutal, o esforço para estabelecer uma facção vitoriosa, com o poder de conduzir a construção da nação, levaria décadas. A Espanha, obviamente, saiu perdedora em todo esse processo, assim como aqueles gachupines (espanhóis europeus) que falharam ao se esquivar da vingança das leis de expulsão direcionadas contra eles. ${ }^{18}$ Contudo, a metrópole deixou para trás sua infraestrutura política, a maior parte do exército monarquista, e uma grande população de antigos defensores do monarquismo que se opunha a mudanças radicais. Até a retirada da guarnição espanhola de San Juan de Ulúa, em 1825, e a derrota da expedição quixotesca de reconquista em 1829, comandada pelo Brigadeiro Isidro Barradas, o rei Fernando VII manteve a crença de que a Espanha poderia reconquistar a sua mais valiosa possessão americana.

${ }^{16}$ Christon I. Archer, "Where Did All of the Royalists Go? New Light on the Military Collapse of New Spain, 1810-1822". In: Jaime E. Rodríguez O. (org.), The Mexican and Mexican American Experience, 24-43; 106-110; e Archer, "Fighting for Small Worlds: Wars of the People during the Independence Era in New Spain, 1810-1821". Cuadernos de Historia de América, N. 6 (1998), 87-92.

${ }^{17}$ Ver, por exemplo, Peter F. Guardino, Peasants, Politics, and the Formation of Mexico's National State, Guerrero, 1800-1857. Stanford: Stanford University Press, 1996. 211-20. Guardino observa que "A política da elite e a política popular estavam entrelaçadas. É impossível analisar uma sem a outra".

${ }_{18}$ Manuel Ferrer Muñoz, La formación de un estado nacional en México. El Imperio y la República Federal: 1821-1835. México: U.N.A.M., 1995. 169-173; e Harold Dana Simms, The Expulsion of Mexico's Spaniards, 1821-1836. Pittsburgh: University of Pittsburgh Press, 1990. 


\section{A herança do conflito e as complexidades da construção da nação}

A hipótese do presente artigo propõe uma abordagem em duas partes distintas da política de exército abrangendo o pensamento político dos oficiais participantes e os significados da militarização e do militarismo no contexto mexicano. De início, a década de guerra 1810-1821 produziu alguns notáveis comandantes-administradorespolíticos do exército, e um sistema militarizado de governança regional e distrital. Sob comandantes poderosos, algumas jurisdições políticomilitares se tornaram, quase, semiautônomas satrapias regionais. Em segundo lugar, na década de 1821-1830, antigos comandantes do exército que haviam dominado regiões e distritos durante os anos de guerra - principalmente monarquistas - agora se engajavam na política no cenário nacional. A conversão destes homens de carreiras militares na política foi bastante notável - incluindo Iturbide, Santa Anna, Pedro Celestino Negrete, Bustamante Anastácio -, e muitos outros. Pelo lado dos insurgentes, apesar de seus esforços prolongados em criar governos e escrever constituições ao longo dos anos de guerra, exceto pelo número relativamente pequeno de apoiadores nas principais cidades e vilas, os antigos insurgentes não tinham experiência dentro da ampla jurisdição militar ou política. Os rebeldes operaram de forma mais efetiva, fora das isoladas e acidentadas regiões montanhosas, florestas, e ambientes lacustres ou pantanosos, os quais representavam preocupações logísticas e de saúde aos seus adversários monarquistas. Eles desenvolveram táticas clássicas de guerrilha e atuaram de forma mais efetiva ao nível de vilas, aldeias e comunidades rurais. Após a independência nacional, com algumas exceções, notadamente Vicente Guerrero e Guadalupe Victoria, a maioria dos antigos comandantes insurgentes não tive êxito no estágio avançado do cenário nacional, como os monarquistas. Demorou algum tempo para as doutrinas e as ideias, focadas no conceito de autonomia local, corroerem as abordagens mais centralizadoras. ${ }^{19}$

Durante os diferentes estágios do conflito multifacetado, de um alto comando sediado na Cidade do México, os monarquistas tomaram conta do planejamento militar e estratégico central. Vice-Reis, Francisco Javier Venegas, Félix Calleja e Juan Ruiz de Apodaca dirigiram todo o aparato militar e as estruturas político-administrativa-econômicajurídica, e, não obstante, as interrupções da guerra eles mantiveram

\footnotetext{
${ }^{19}$ Ver, por exemplo, Peter F. Guardino, 1996.
} 
o sistema borbônico centralizado de governo. Durante esse período, os vice-reis e seus planejadores de guerra viram o conflito em sua totalidade, bem como nas suas complexas e confusas partes. A estrutura militar monarquista controlou comunicação, transporte, e tentou, com limitado sucesso, muitas vezes acompanhar lado a lado as operações do dia a dia. No entanto, devido à natureza fragmentada e regionalizada do conflito, tanto a insurgência quanto a contra-insurgência avançaram e entrincheiraram poderosos elementos de descentralização. Mesmo quando comboios armados permitiam a transferência de lingotes de prata, gado, algum comércio e a manutenção de comunicação essencial, regiões inteiras foram isoladas por meses, ou mesmo por anos, pelas atividades endêmicas da guerrilha insurgente. ${ }^{20}$

Para todo o seu vaidoso poderio enquanto força de combate convencional, em alguns anos, o exército monarquista falhou em manter abertas as mais estratégicas artérias conectando a Cidade do México, através de Jalapa, Orizaba e Córdoba ao porto de Veracruz. As múltiplas demandas e missões das tropas monarquistas fragmentaram regimentos e batalhões que, designadas para funções de guarnição, patrulhas e comboios, deixaram poucas companhias disponíveis para formar forças de campo operacionais e destacamentos volantes. ${ }^{21} \mathrm{O}$ ineficiente sistema de transporte por comboios fortemente escoltados possibilitou aos comandantes a requisição de mulas e tropeiros, e a empreender uma variedade de práticas corruptas. Alguns comandantes distritais monopolizaram o comércio e as comunicações, cobravam impostos ilegais, extorquiam propina de mercadores e traficantes, e abriram seu próprio negócio para vender as mercadorias confiscadas de insurgentes ou não reclamadas pelos antigos proprietários. Governadores militares e políticos, provinciais ou regionais, controlavam organizações que combinavam as jurisdições políticas e militares. Em algumas regiões, estes chefes militares exerceram controle quase ditatorial sobre o plano político, econômico, social e na vida do seu povo.

Em Jalapa, o Brigadeiro Joaquín del Castillo y Bustamante, Governador político e militar, poderoso fazendeiro e comerciante, bem como experiente comandante de exército, dominou todos os aspectos da vida em sua jurisdição. Em 1820, o administrador do serviço de correios

${ }^{20}$ Christon I. Archer, "La Causa Buena": The Counterinsurgency Army of New Spain and the Ten Years' War". In Jaime E. Rodríguez O. (org.). The Independence of Mexico and the Creation of the New Nation Los Angeles: UCLA Latin American Center Publications, 1989. 85-108.

${ }^{21}$ Archer, 1989, p. 85-108. 
em Jalapa, Faustino de Capetillo, queixou-se que, durante o seu governo de seis anos, Castillo y Bustamante oprimiu o povo que "viu a liberdade civil destruída e o fomento da discórdia." Ele concedeu varas de justicia para seus seguidores que eram "vengativos y viciosos" em seus esforços de destruir os moradores mais honrados e que abandonavam prisioneiros infelizes nas prisões. ${ }^{22}$ Com o advento da Constituição Espanhola, em 1820, aparentemente, quase todos em Jalapa esperavam a transferência de Castillo y Bustamante, mas isso não ocorreu. Com escandaloso desrespeito à lei que ele jurou cumprir, mesmo após as eleições locais, ele tentou dominar as alcades constitucionales. No intuito de se livrar de Castillo y Bustamante, o Ayuntamiento de Jalapa circulou uma petição que o acusava de se opor à Constituição. ${ }^{23}$ Talvez, influenciado pela mudança no cenário político na Nova Espanha, e consciente do fato de que todas as coisas boas chegam ao fim, Castillo y Bustamante solicitou a renovação de uma licença antiga para retornar mais cedo à Espanha! ${ }^{24}$

Outros comandantes, frequentemente nos seus esforços para ganhar posições e riqueza na guerra, desrespeitaram abertamente às leis e à jurisdição de subdelegados e outros burocratas das intendências provinciais. Até mesmo os vice-reis, na qualidade de capitães gerais, descobriram que suas ordens diretas às vezes eram difíceis ou impossíveis de serem aplicadas em um país fragmentado pela guerra. Comandantes regionais seguiram suas próprias políticas e, se necessário, culpavam estradas interditadas e despachos capturados pelos atrasos na aplicação de normas e políticas específicas. ${ }^{25}$ Embora fosse difícil de rastrear as atividades ilegais dos oficiais do exército monarquista, houve alguns escândalos notáveis envolvendo o Coronel Agustín de Iturbide, Comandante Guanajuato e Comandante do Exército del Norte, Brigadeiro Melchor Alvarez, o Comandante de Oaxaca, e o Capitão Antonio López de Santa Anna, que obrigaram as mais altas autoridades

${ }^{22}$ Faustino de Capetillo, Administrador de Correos de Jalapa ao Governador José Dávila, 6 de julho de 1820, Archivo General de la Nación, Mexico, Sección de Operaciones de Guerra [Citado doravante como AGN: OG], vol. 266.

${ }^{23}$ Requerimento do Ayuntamiento de Jalapa, 10 de julho de 1820, AGN: OG, vol. 216.

${ }^{24}$ Vice-Rei Conde de Venadito (Juan Ruíz de Apodaca) ao Ministro de Hacienda, n. 1.101, 31 de julho de 1820, Archivo General de Indias, Sevilla, Sección de Méjico [Citado doravante como AGI, Mexico], Legajo 2.420.

${ }^{25}$ Ver Christon I. Archer. "Politicization of the Army of New Spain during the War of Independence, 1810-1821”. In Jaime E. Rodríguez O. (org.). The Evolution of the Mexican Political System. Wilmington, Delaware, Scholarly Resources Inc., 1993. 17-43; e Archer, "The Militarization of Mexican Politics: The Role of the Army, 1815-1821". In: Virginia Guedea e Jaime E. Rodríguez O. (orgs.). Five Centuries of Mexican History/Cinco siglos de historia de México, I . México: Instituto Mora, 1992. 285-302. 
militares a investigar e aos vice-reais a agir. ${ }^{26}$ É interessante destacar que todos esses três oficiais superaram os críticos e os seus próprios registros duvidosos, para ditar as regras em eventos posteriores. Iturbide e Santa Anna alcançaram reconhecimento e, pelo menos temporariamente, sucesso, que superou quase todos os outros oficiais-políticos na época pós-Independência.

Uma área de problemas crônicos diz respeito à manipulação dos comboios comerciais por comandantes militares que desviavam fundos em taxas especiais, processo que criou uma avalanche de queixas dos consulados, ayuntamientos, organizações mineiras, e qualquer um envolvido com o transporte de cargas. Desde o início da guerra, os insurgentes obstruíam estradas, em alguns casos, recolhiam seus próprios impostos, e tentavam impedir a passagem de carregamentos de prata, expedições, provisões e quaisquer outros itens de valor de comércio. Em 1811, uma junta de antigos comerciantes burocratas da mineração propuseram que os Consulados do México, Guadalajara e Veracruz e o Tribunal de Minería estabelecessem novos impostos, aumentando para 150 mil pesos anuais, para o pagamento de escoltas militares a comboios comerciais. ${ }^{27} \mathrm{O}$ Vice-Rei Venegas argumentou para a posição que outra taxa deveria ser criada para estabelecer um camino militar com 1.200 a 1.500 soldados de cavalaria para manter as estradas abertas entre a Cidade do México e Veracruz. ${ }^{28}$

Tanto os comerciantes quanto os mineiros da Nova Espanha foram incisivos em suas respostas, que o regime do vice-rei e o exército pretendiam saquear seus recursos limitados com o objetivo de financiar defesas monarquistas contra a insurreição. Os comerciantes de Veracruz particularmente se opuseram ao aumento de dois por cento do imposto sobre o comboio para pagar o camino militar. Eles argumentaram que, se entrasse em vigor o novo imposto, a importação e a exportação anual de tráfego em Veracruz, avaliado em cerca de vinte e um milhões de pesos, produziria uma renda de 420 mil pesos. Uma vez que, a estrada defendida custaria cerca de 500 mil pesos, o consulado argumentou que o tráfego marítimo do porto não suportaria o encargo de pagar as defesas terrestres. ${ }^{29}$ Diante deste cenário e da tradição regional e distrital

${ }^{26}$ Ver, Christon I. Archer. In: Jaime E. Rodríguez O. (org.), 1993, p. 34-39.

${ }^{27}$ Juan Bautista Lobo ao Prior y Consules del Real Tribunal del Consulado de Veracruz, 30 de junho de 1811, AGN: OG, vol. 215.

${ }^{28}$ Vice-Rei Miguel Xavier de Venegas ao Consulado de México, 4 de julho de 1811, AGN: OG, vol. 215.

${ }^{29}$ Consulado de Veracruz a Venegas, 7 de dezembro de 1811, AGN: OG, vol. 215. 
de resistência ao governo central, não é de estranhar que os elementos civis, dentro e fora dos ayuntamientos, opuseram-se aos regimes fiscais, originado no regime central e no comando militar.

Quando o exército passou a competir diretamente com o setor civil no transporte de mula, a luta entre o regime e os poderosos comerciantes regionais e mineiros, sobre a tributação de defesa, tornou-se ainda mais amarga. Em todo o País, os comandantes do exército requisitavam mulas e cavalos, tanto para uso militar quanto para fins duvidosos, para extorquir fundos, alegando que o esforço de defesa contra a insurreição exigia a primazia das necessidades militares. Até 1813, a chegada dos batalhões expedicionários europeus na Nova Espanha colocou mais pressão sobre os transportes disponíveis. No mesmo ano, o Brigadeiro José Olazabal, comandante do Ejército del Sur, expressou a frustração sobre a insuficiência de mulas disponíveis para transporte de bagagens, artilharia, munições e suprimentos dos batalhões recémchegados pertencentes aos Regimentos de Infantaria Expedicionária de Zamora e Castilla. ${ }^{30}$ Os ataques destrutivos de vomito negro e as tropas peninsulares não-aclimatadas requereram organização e velocidade em movimentação das tropas para o interior.

Infelizmente, o comportamento arrogante dos oficiais europeusespanhóis exacerbou antigas rivalidades na Nova Espanha, especialmente, em Veracruz. Isso enfatizou a antipatia aguda entre os criollos e os oficiais arrogantes do exército gachupin, residentes antigos da Nova Espanha, os quais tensionaram as relações, ameaçando a requisição de mulas, ou, a utilização dos impostos locais para pagar seus soldados. Em 1815, por exemplo, a chegada do Regimento de Infantaria Expedicionária de Ordenes Militares e o Batalhão de Voluntários de Navarra - 1.718 soldados comandados pelo Brigadeiro Fernando Miyares y Mancebo protagonizaram acirradas disputas e deixaram um forte ressentimento na população de Veracruz. Excedendo a autoridade de que eram investidos, para disfarçar o medo de contrair o vomito negro, os espanhóis requisitaram todos os cavalos da milícia local, assumiram as carroças pertencentes às autoridades policiais, e marcharam imediatamente para o planalto. ${ }^{31}$

Em reação as pesadas ações militares, o Consulado de Veracruz resistiu ao exército e as políticas que os comerciantes descreveram como

\footnotetext{
${ }^{30}$ Governador e Intendente de Veracruz José de Quevedo ao Prior do Consulado de Veracruz, 10 de fevereiro de 1813, AGN: OG, vol. 215.

${ }^{31}$ Governador interino Pedro Quevedo ao Vice-Rei Félix Calleja, 18 de junho de 1815, AGN: OG, vol. 698.
} 
a negativa militarização do porto e da economia provincial. Começando em 1813 e permanecendo até a obtenção da Independência sob o Plano de Iguala, os comerciantes de Veracruz, como muitos outros na Nova Espanha, desenvolveram crescente atitude antimilitar. Isso resultado direto das insaciáveis demandas do exército monarquista por fundos adicionais e poder. Os comerciantes do porto apontaram que, desde o início da guerra, fizeram imensos sacrifícios para fornecer suporte financeiro para a guarnição de Veracruz e para a defesa da província. Em muitas ocasiões, eles ofereceram fundos de emergência para receber batalhões expedicionários espanhóis que chegavam à Nova Espanha, por vezes, sem condições de prover sua subsistência. Durante muitos bloqueios rebeldes ao longo das estradas para o interior - alguns destes durando meses ou mesmo mais de um ano - eles pagaram os salários das tripulações navais mercantes em atraso no porto. Como outros mercadores e comerciantes, eles lamentaram a redução dos seus rendimentos e a perigosa diminuição de moeda disponível na economia. Com o comércio paralisado, e os gastos privados e públicos voltados para o esforço de guerra, o consulado de Veracruz informou o Vice-Rei Félix Calleja que os comerciantes não podiam pagar mais. A cidade já havia levantado um empréstimo de 300,000 pesos para a guerra, aceitando um aumento de dez por cento em impostos sobre a propriedade rural e urbana, e um aumento de dois por cento sobre os impostos de comboio para angariar fundos para a construção do camino militar para Jalapa. ${ }^{32}$

Apesar dessas iniciativas de defesa dos monarquistas, em 1815 os bandos insurgentes da província de Veracruz interditaram com sucesso o comércio, atacaram postos do exército e fizeram uma completa zombaria dos esforços monarquistas para defender o Camino Real. Com apurado conhecimento das acidentadas montanhas, florestas, barrancos e com inata habilidade de agir efetivamente no clima mortificante, fez de Veracruz território privilegiado para pequenos bandos guerrilheiros, os quais lutaram sozinhos ou coligados com outras forças rebeldes para atacar duramente cidades monarquistas, haciendas, guarnições e os comboios. Em parte, os bandos insurgentes financiaram suas atividades através da coleta de impostos pagos pelos viajantes e por expedições comerciais entre Córdoba, Jalapa e Veracruz. A resposta

${ }^{32}$ Consulado de Veracruz ao Conde de Castro Terreño, Comandante Geral do Exército do Sul, 17 de maio de 1813; e Consulado de Veracruz a Calleja, 12 de junho de 1813, AGN: OG, vol. 215. 
dos comandantes monarquistas foi colocar cada vez mais restrições sobre viagens e proibições contra o despacho de qualquer carregamento comercial sem escolta oficial. O desemprego produzido pelo conflito e o deslocamento econômico geral da província obrigaram muitas pessoas a aderir à rebelião. ${ }^{33}$

Embora os bloqueios de insurgentes na província de Veracruz possam ser vistos mais como um grande incômodo do que uma crise divisora de águas na guerra, a realidade da situação foi que os insurgentes conseguiram frustrar o exército monarquista, cortando as comunicações com a Espanha, por períodos de longos meses. Tal crise produziu um impacto correspondentemente negativo na economia através do país sobre os mercadores, os mineiros e os viajantes. Ao longo do tempo, os bloqueios e os desastres econômicos compeliram o povo a reavaliar seu compromisso com as soluções militares e a considerar outros meios para alcançar a paz. As atividades insurgentes na província de Veracruz, por exemplo, no final de outubro de 1814, forçou a escolta de um grande comboio armado, que partiu da Cidade do México, com quase 2,7 milhões de pesos, pertencentes a comerciantes particulares e a Coroa, a parar por mais de cinco meses e meio em Jalapa. Passageiros do comboio que viajavam de carroças, a cavalo ou a pé, tiveram de procurar alojamento em Jalapa. Muitos experimentaram graves dificuldades, tendo que vender seus bens para pagar suas estadias. Alguns comerciantes venderam suas mercadorias a preços ridiculamente baixos, arruinando a economia local, e a maioria dos mayordomos, proprietários de mulas e empregadores de tropeiros, eventualmente sofreram ruína financeira. Alguns dos maiores comboios de guerra empregavam mais de 400-500 tropeiros que cuidavam de 2.000 a 3.000 mulas, incluindo animais sobressalentes, de reposição e necessários para o transporte de carga pesada. ${ }^{34}$

Durante 146 dias de espera inativa, o comandante do comboio parado em Jalapa, Coronel Luis del Aguilar, gastou 1.425 pesos em despesas pessoais e tomou uma atitude quase sem precedente de quebrar o carregamento selado de moedas de prata para a requisição de 139.382 pesos, quatro e meio reales, para pagar as tropas do comboio de

${ }_{33}$ Ordem Real do Vice-Rei Calleja, 4 de abril de 1814, AGN: OG, vol. 216. Por esta ordem, Calleja pôs fim ao comércio sem escoltas militares.

34 Ver, por exemplo, Estado que manifiesta los arrieros, mulas, cargas del comercio, de Hacienda Pública, salidas de Veracruz en el presente convoy del mando de Teniente Coronel Saturnino Samaniego, Puebla, 3 de dezembro de 1813, AGN: OG, vol. 215. 
escolta. ${ }^{35}$ No futuro, guarnições de exército e divisões de comandantes ao longo das rotas para o litoral passariam a ver os comboios, vindos do interior, transportando carregamentos de peso cunhado como um presente divino. Nesse meio do tempo, o navio de guerra da Marinha Real Prueba, que estava ancorado em Veracruz desde agosto de 1814, e vários outros navios mercantes, aguardavam a chegada do comboio. Sem acesso a provisões dos produtores do interior e devido ao bloqueio naval britânico dos portos americanos durante a Guerra de 1812, a cidade de Veracruz foi incapaz de comprar provisões suficientes para alimentar a população. Como resultado direto, em 1815, uma epidemia de escorbuto e disenteria devastou a população, que havia resistido a outras formas de doenças. O consulado queixou-se ao Vice-Rei Calleja que a redução da cidade portuária a "indigência total" não foi de todo positiva para "al feliz éxito de la buena Causa." ${ }^{36}$ Mais uma vez, líderes civis tinham bons motivos para procurar formas de acabar com a guerra e para limitar as atividades dos militares.

Plenamente consciente das falhas e dos abusos dos militares, os mercadores de Veracruz pediram a intervenção direta do governo imperial. Escrevendo para o Secretário de Estado e do Despacho Universal das Índias, criticaram o exército monarquista e o vice-rei por proibir o comércio sem escoltas e por falhar em prestar um serviço adequado. O resultado foi a paralisação "mortal" do comércio interno e externo e a redução à pobreza para muitos comerciantes. Com o campo devastado e as perdas nos negócios que o consulado estimou em setenta milhões de pesos, desde o início da guerra, os comerciantes que ainda eram capazes de pagar começaram a fugir para a Espanha. $\mathrm{O}$ consulado particularmente resistiu à proibição da escolta ao comércio, ressaltando que os danos econômicos foram muito piores do que se os arrieros simplesmente tivessem pagado as tarifas dos insurgentes. Muitos dos bandos rebeldes próximos à cidade portuária operavam junto às estradas para que pudessem atacar de surpresa os tropeiros e os pequenos atravessadores em novas disposições que entravam e saiam. ${ }^{37}$

\footnotetext{
35 Juan Montoto y Garza, Diputado del Comercio en el presente ao Prior e Consules do Consulado of Veracruz, 18 de abril de 1815, AGN: OG, vol. 216. Durante o comboio de outubro de 1815, da cidade de México, o coronel José Joaquín Marqués sacou 15.168 pesos em Jalapa para arcar com as despesas da sua divisão. Ver Consulado de Veracruz a Calleja, 8 de janeiro de 1816, AGN: OG, vol. 217.

${ }^{36}$ Consulado de Veracruz ao Vice-Rei Calleja, 13 de abril de 1815, AGN: OG. vol. 216.

${ }^{37}$ Ibid.
} 
O consulado de Veracruz culpou alguns dos comandantes militares por exagerar a real situação para os seus superiores na Cidade do México. O resultado produziu a proibição total do comércio sem escolta, que interrompeu o fluxo de comércio com o interior do País. A chegada da absoluta estagnação econômica foi um dos mais intensos esforços que o inimigo conseguiu completar. Os comerciantes reclamaram amargamente que viviam oprimidos como sujeitos de "el imperio de las bayonetas". Em 1815, o exército tentou cinco operações - requisitando quase todas as mulas de transportes disponíveis - para esmagar a fortaleza insurgente de Zopilote e para destruir as barreiras e as valas que interditavam a principal estrada em Antigua. Em vez de atacar as posições diretamente, contudo, os comandantes monarquistas procuraram estradas secundárias, e mesmo abriram novas rotas através do terreno acidentado. Todo o tempo os oficiais queixaram-se amargamente sobre o calor opressivo e o clima nocivo do País. Contrariamente aos oficiais do exército que reivindicaram a presença de um número significante de inimigos, o consulado estimou pelas suas próprias fontes de informação local que havia apenas cerca de seiscentos insurgentes ativos no distrito de Antigua. Os ressentimentos aumentaram quando os comerciantes de Veracruz observaram que, quando comboios chegavam até a costa, o regime continha prata e outros bens preciosos, mas raramente incluíam comida e outros itens de primeira necessidade para o consumo na cidade portuária..$^{38} \mathrm{O}$ consulado assinalou que, mesmo durante a ocupação da Espanha, Cádiz havia sido autorizada a comerciar com países ocupados por "El Tirano de Europa". No caso do estratégico porto de Veracruz, o sistema militar excessivamente restritivo da Nova Espanha reduziu as trocas comerciais ao litoral.

A disputa amarga sobre o comércio ferveu ao longo dos anos restantes da guerra. No entanto, em 1817, quando os exércitos monarquistas alcançaram sucesso em empurrar temporariamente os insurgentes de Veracruz, o Vice-Rei Apodaca retirou a obrigatoriedade de escoltas militares para todos os comboios comerciais. Com o retorno de relativa tranquilidade e segurança, a cidade portuária experimentou o renascimento imediato do comércio, o que atraiu tropeiros com mulas e burros e índios a pé, os quais viajaram grandes distâncias entre Mixteca e Guadalajara para comerciar suas mercadorias. Novamente, a economia prosperou em Veracruz e os mercados se encheram de produtos baratos e

\footnotetext{
${ }^{38}$ Consulado de Veracruz ao Secretario de Estado y del Despacho Universal de Indias, 23 de junho de 1815, AGN: OG. Vol 216.
} 
de boa qualidade. Em 1819, porém, os insurgentes retomaram os ataques às estradas no interior de Veracruz, que levou o vice-rei a restabelecer 0 sistema restritivo aos comboios. Os comerciantes de Veracruz ficaram furiosos - insistiam que manter o comércio aberto era absolutamente essencial e alertaram que a combinação de desemprego e escassez de alimentos levaria muitos lojistas a se juntarem ao lado dos rebeldes. Eles alertaram que a reintrodução de comboios produziria um monopólio de três ou quatro grandes proprietários e mayordomos, os quais controlavam as maiores manadas de animais de tração. Esses indivíduos aumentariam as tarifas de frete e negociariam contratos de monopólio com os mais ricos - deixando pouca ou nenhuma oportunidade de negócio para os pequenos comerciantes e arrieros. Esses tropeiros, que possuíam apenas poucos animais e os pequenos atravessadores que forneciam provisões à cidade portuária, certamente ficariam de fora dos negócios. ${ }^{39}$ Frustrações com a guerra e com a centralização das decisões na Cidade do México agravaram os ressentimentos de Veracruz e, posteriormente, aumentaram o apoio do setor civil pela autonomia regional. Nos anos iniciais da pós-Independência, os habitantes de Veracruz procuraram o apoio e a proteção do General Antonio López de Santa Anna, o qual, como político, deu atenção aos assuntos da sua província natal.

Em um conflito envolvendo a insurgência e a contrainsurgência, oficiais do exército enfrentaram desafios militares e políticos que estavam completamente fora de sua experiência militar. Conscientes de que uma má decisão ou um desastre no campo de batalha poderia produzir um resultado que permanentemente arruinaria suas carreiras, a partir do início da guerra, alguns dos mais antigos comandantes do exército procuraram refúgio fora das zonas de guerra. Uma vez que uma trajetória sem manchas era, sobretudo, o elemento mais importante na construção de uma hoja de servicio (fé de oficio) de um oficial, servir em uma guarnição sedentária com apenas ocasionais perseguições a guerrilheiros insurgentes era bastante desagradável e também apresentava muitas armadilhas potenciais. Uma batalha perdida ou a conexão de um oficial a abusos envolvendo civis poderia danificar ou mesmo arruinar a mais promissora das carreiras militares. Alguns oficiais ansiavam por posições seguras para resistir a uma guerra desorganizada, em que praticamente não existiam as batalhas convencionais gloriosas e sem as regras que regem uma guerra civilizada.

${ }^{39}$ Consulado de Veracruz ao Vicerei Conde de Venadito (Apodaca), 9 de junho de 1819, AGN:OG, vol. 217. 
O Brigadeiro José de la Cruz, Comandante Geral de Nueva Galicia, um rígido comandante do exército espanhol, que nunca fugiu ao dever ou a decisões difíceis, informou Félix Calleja, em 1811, "Yo voy conociendo muy de cerca que cierta clase de hombres en este Nuevo Mundo son enteramente diversos que los que conocenos." ${ }^{40}$ Ele chegou à Nova Espanha em 1810, e passou a trabalhar imediatamente como um comandante da contra-insurgência dedicado à extirpar os bandos rebeldes que surgiram na esteira de Cura Miguel Hidalgo. Para Cruz, a falta de compromisso e dedicação total pelos seus irmãos de armas - especialmente comandantes do alto escalão - foi um choque. Nas palavras ditas com ironia, em abril de 1811, ele comentou para Calleja,

Que Suerte tan diferente hemos tenido nosotros en la presente sublevación que el que han tenido nuestros ilustres companheiros de armas, Brigadieres Salcedo Nemésio, Bernardo Bonavía, y Alejo García Conde!" Salcedo se certificou em permanecer nas Provincias Internas longe da insurgência, Bonavía manteve-se seu "en su conejera de Durango", e quando a revolta eclodiu, García Conde "partió como un rayo a Arizpe al cuidado de su gobierno." Com desprezo, Cruz concluiu: "Ellos tendrían mucha mejor suerte que nosotros y su reputación será sin mancha, ni aun recelos de perderla, mientras que aquí estamos expuestos a um accidente que sin comerlo ni beberlo nos de um sofocón que nos envie al outro barrio! ${ }^{41}$

O que Cruz deixou de mencionar foi que esses oficiais eram de outra geração - mais velha, acostumada ao serviço sedentário dos tempos de paz, e, como muitos de seus contemporâneos, completamente incapazes de fazer a difícil transição a um tempo de guerra e de combater em uma guerra sangrenta e complexa. ${ }^{42}$ Embora ele se manteve fiel à Espanha, Cruz, como muitos dos jovens oficiais, que sobreviveram ao conflito e fizeram suas carreiras no México independente, propôs métodos agressivos para reprimir a rebelião. Ele informou Calleja que: "Vamos a esparcir de terror y la muerte por todas partes, y que estos malvados han desdeñado recibir el perdón con que los hemos convidado, y en

\footnotetext{
40 José de la Cruz a Félix Calleja, 18 de abril de 1809, AGN:OG, vol. 145.

${ }^{41}$ Cruz a Calleja, Guadalajara, 8 de abril de 1811, AGN:OG, vol. 145.

42 Ver oficiais superiores do Exército da Nova Espanha, 1811, in: Archivo General de las Indias, Sevilla, Sección 5 de Méjico [citado doravante como AGI, Mexico], legajo 1321. O Brigadeiro Bonavía faleceu em 1816 e sua viúva, Doña Clara de Torre, requereu e recebeu licença para retirar-se a Espanha. VerVice-Rei Juan Ruíz de Apodaca ao Ministro de Hacienda, n. 190, 7 de agosto de1817, AGI, México, legajo 2420.
} 
fin vamos a que no quede un perverso sobre esta tierra. Ya no hay un término medio que emplear con estos bribones." 43 Como se poderia prever, esse grande entusiasmo ou o comprometimento dos comandantes monarquistas produziu um descaso geral com qualquer obstáculo ou jurisdição que ficasse no caminho da absoluta aniquilação da insurgência. As sutilezas legais ou constitucionais provocavam pouco respeito nos oficiais que dedicavam sua atenção, exclusivamente, a atingir a vitória total. Para provocar o impacto total do terror da contra-insurgência, os comandantes, como Cruz, queriam permitir o acesso sem entraves dos militares ao poder. Uma vez que os monarquistas representavam "la causa buena" contra "la causa mala", o sistema estava "... el pasar cientos por las armas, diezmar pueblos, y hacer el nombre del soldado tan temible como la muerte misma." 44 Cruz frequentemente se referia ao exemplo saudável de pendurar os cadáveres dos rebeldes nas portas das cidades e insistia que eles aterrorizariam completamente a população. Ele insistiu que na Nova Espanha “... el germen de insurrección está demasiado gravado para que desaparezca sin muchos y ejemplares castigos." 45

Por um lado, a resposta monarquista à rebelião foi a militarização do governo das cidades, das vilas e dos distritos rurais. O plano políticomilitar de Félix Calleja, de 08 de junho de $1811^{46}$, propunha um sistema detalhado de contrainsurgência, o qual requeria oficiais das cidades, aldeias e localidades rurais para aumentar as unidades de milícias pagas por suas comunidades, especialmente por meio de cobrança de impostos locais. O conceito foi obrigar as cidades e os distritos a criar forças de autodefesa, libertando assim o exército para operações específicas contra as forças rebeldes coligadas. Durante anos, os monarquistas obrigaram homens locais a servir em guarnições pagas através da aplicação de impostos chamados eufemisticamente de contribuciones militares. Em alguns bairros, os proprietários pagavam impostos anuais com base em suas terras e renda. Embora esse programa de militarização fosse impopular e produzisse dificuldades significativas para os artesãos, os trabalhadores e os agricultores, em algumas partes do país, a insurreição

${ }_{43}$ Cruz a Calleja, Guadalajara, 8 de abril de 1811, AGN: OG. Vol. 145.

${ }^{44}$ Cruz a Calleja, 15 de julho de 1811, AGN: OG. Vol. 145.

${ }^{45}$ Cruz a Calleja, 2 de janeiro de 1811, AGN:OG. Vol. 143; e Cruz a Calleja, Huichapan, 2 de dezembro de 1810, AGN: OG. Vol. 140.

${ }^{46}$ Reglamento político militar que deberán observar bajo las penas que señala los pueblos, haciendas, y ranchos a quienes se comunique por las autoridades legítimas y respectivas.., Aguascalientes, 13 de junho de 1811, AGN: OG. Vol. 278. Ver também Christon I. Archer. The Counterinsurgency Army and the Ten Years' War, 96-97. 
foi mantida sob controle pela duração de toda a década de guerra graças a ela. Ao longo do tempo, no entanto, o plano político militar esgotou os milicianos e suas famílias. A remoção de muitos assalariados, muitas vezes, por longos períodos, criou dificuldades econômicas, escassez de trabalho e deserções dos homens que fugiram de suas regiões de origem. Seu objetivo era escapar da exigência do serviço de milícias ou do tratamento arbitrário por comandantes de patriotas que ocupavam cargos da milícia vice-real como capitães. Oficiais do exército regular tendiam a depreciar esses homens e, muitas vezes, eles se recusaram a reconhecer a sua posição ou autoridade.

No distrito e na cidade cabecera de Pachuca, por exemplo, com oito cidades e vilas e cinco comunidades mineiras, o Vice-Rei Venegas encarregou Francisco de Paula Villaldea, um rico comerciante dono de uma mina e hacendado, de aumentar, manter e comandar as forças de defesa locais. Villaldea recebeu ordens para designar três esquadrões de carabineiros montados que estavam estacionados em Pachuca, Actopan, e Zempoala e um grande número de companhias de infantaria para patrulhar e guardar os portões da cidade, os muros e as torres de guarda. Armados com lanças e facões ou rifles e pistolas, se disponíveis, os carabineiros também formavam esquadrões designados para patrulhas rurais, para a proteção de estradas, e vigia da pecuária e da agricultura. O elemento-chave dessas forças de defesa foi a seleção de uma junta de arbitrios (comitê de tributação), composta pelo subdelegado do distrito, pela cura local, por dois indivíduos bem respeitados de Pachuca como cabecera, e um delegado de cada cidade ou vila da jurisdição. Apoiados pela experiência do funcionário do tesouro local e pelo diputado mineiro, o primeiro dever da junta foi o de estabelecer contribuciones de milícias que, neste distrito, eram taxas cobradas sobre a prata refinada produzida em lojas, mercado de pecuária, produção de grãos, e culturas agrícolas. ${ }^{47}$

Para maior preocupação da população, o comandante militar e a junta de arbítrios recolheram dados censitários da população para estabelecer contribuciones obligatorias (às vezes chamadas de contribuciones patrióticas) cobradas a título de bens ou rendimentos dos impostos sobre todos os residentes, de acordo com a sua riqueza total estimada. Ninguém ficou isento e até mesmo os habitantes mais pobres tinham de fazer pelo menos um pagamento mínimo. ${ }^{48}$ Hacendados e

\footnotetext{
47 Vice-Rei Venegas a Francisco de Paula Villaldea, 2 de agosto de 1812; e Villaldea a Venegas, Pachuca, 24 de agosto de 1814, AGN: OG. Vol. 894.

${ }^{48}$ Relatório de Villaldea, 23 de março de 1812, AGN: OG. Vol. 894.
} 
rancheros pagavam taxas de acordo com o valor de todos os seus bens - um fator que produziu raivosa resistência daqueles que afirmaram que os bandos insurgentes tinham ocupado suas propriedades durante anos e que eles não recebiam renda de outras terras abandonadas por agricultores ou estocadores. As contribuciones obligatorias eram um fardo particularmente pesado para os moradores das vilas, que muitas vezes não tinham acesso à moeda e sofriam com o falta de trabalho, quebras de safras, epidemias e atividades insurgentes. Em 1814, o governador indiano de Tezontepec (sujeito à Pachuca) lamentou que sua comunidade estava em atraso de cinquenta pesos em sua arrecadação de impostos da milícia. Algumas mulheres que não podiam pagar um único real tiveram que vender suas próprias roupas e a maior parte dos homens deixou a comunidade para procurar trabalho em outro lugar. ${ }^{49}$ Embora isso possa soar como uma situação extrema ou como caso falso, muitas outras comunidades fizeram repetidas queixas de abusos semelhantes por parte das autoridades da milícia local.

\section{O retorno da Constituição Espanhola}

A manifestação de entusiasmo para o restabelecimento da Constituição Espanhola em 1820, e a eleição de ayuntamientos constitucionales e diputaciones provinciales em quase todas as regiões e os distritos de Nova Espanha, estavam diretamente relacionadas ao esgotamento da guerra e a oposição à tributação abusiva das milícias. Além disso, era bastante óbvio que, enquanto o exército monarquista da Nova Espanha havia alcançado um impasse, não havia esperança legítima de uma vitória total..$^{50} \mathrm{~A}$ força da reação contra a militarização da sociedade e o entusiasmo espontâneo por um processo nacional de desmobilização foi bastante notável. Além disso, a Constituição proibiu o alistamento arbitrário dos assim chamados "vagabundos", o que havia sido usado como dispositivo legal para angariar jovens para os regimentos regulares do exército. ${ }^{51}$

Em 1820 e, posteriormente, as pessoas começaram a abordar uns aos outros como ciudadano ou ciudadana e, às vezes, se recusavam a

\footnotetext{
${ }^{49}$ Frei Francisco Javier Viera, Cura de Tezontepec, a Vice-Rei Venegas, agosto de 1814; e Relatório de George Alejandro, Gobernador de Tezontepec, a Venegas, agosto de 1814, AGN: OG. Vol. 894. Para uma comparação interessante, ver Lista de la Contribución Patriótica Militar del Partido de Tlayacapa para el mes de agosto de 1820. AGN: OG. Vol. 377.

${ }^{50}$ Brigadeiro Domingo Luaces a Vice-Rei Venadito, n. 119, Querétaro, 17 de julho de 1820.

51 Vice-Rei Venadito a Luaces, 16 de dezembro de 1820, AGN: OG. Vol. 512.
} 
reconhecer as autoridades constituídas legalmente. Nas cidades, clubes e juntas de advogados, comerciantes, burocratas e oficiais do exército se reuniram para discutir os conceitos de liberdade e independência. Havia um tom definitivamente antigachupín nas muitas conversas e demandas para a destruição e expulsão de todos os abusivos gachupines. Em Guadalajara, José de la Cruz propôs o fim imediato das destrutivas subdivisões que eram comuns nas unidades do exército e a interrupção das transferências de regimentos e batalhões para longe das províncias onde eles haviam servido por muitos anos. Em 04 de outubro de 1820, Cruz tornou-se mais preocupado com o comportamento desrespeitoso, reuniões clandestinas, denúncias anônimas, e outros sinais de inquietação. Ele escreveu ao Vice-Rei Venadito “... Todo cuanto el percibe da indicios que estamos sobre um volcán." ${ }^{2}$ Outras cartas se referiam a sugestões, semelhantes em alguns aspectos, que logo apareceram como propostas no Plano de Iguala. Muitas recomendavam a remoção imediata dos regulamentos militares restritivos a viagens e a exigência de que todos os viajantes tivessem de carregar passaportes oficiais. A flexibilidade de movimento permitiu um maior intercâmbio de ideias e soldados desertados a retornarem às suas casas. Pessoas comuns zombavam das patrulhas militares, das autoridades policiais e dos oficiais que os mantiveram sob rigoroso controle durante uma década. Nas estradas, os oficiais se queixavam que desde então quase todas as pessoas carregavam armas, era difícil identificar entre ladrões e bandidos os sujeitos legítimos. ${ }^{53}$

Mesmo em mundo sem comunicação de massa, a forte rejeição aos impostos militares varreu a Nova Espanha e, em alguns aspectos, deu início à derrocada do regime monarquista. Este processo, em 1820, teve um efeito dominó, que levou à destruição, ou melhor, à implosão do exército monarquista para a corrida espetacular dos oficiais de exército e soldados para apoiar o Plano de Iguala de Iturbide. Eles se juntaram à gloriosa e quase sem derramamento de sangue marcha vitoriosa do Exército das Três Garantias. Não obstante, o fato de tudo isso ser muito fácil e não resolver os verdadeiros problemas econômicos e políticos, por um curto espaço de tempo, pelo menos por enquanto o entusiasmo pela causa de Iturbide disfarçou as profundas fraturas e divisões dentro da sociedade mexicana. Uma vez que a opressão do regime monárquico

52 Cruz a Venadito, 4 de outubro de 1820; e José María Alfaro a Manuel Pesquera, Valladolid, 12 de setembro de 1820, AGN: OG. Vol. 157.

${ }_{53}$ Brigadeiro Ciriaco de Llano, Capitán General e Intendente de Puebla, a Venadito (reservado), 12 de outubro de 1820, AGN: OG. Vol. 461. 
terminou, a corrida para a liberdade como foi percebida produziu centenas de ayuntamientos constitucionais que não aceitaram sua antiga subserviência às cidades cabecera, às representações provinciais, ou ao governo centralizado na Cidade do México.

Os relatórios escritos em 1820 por muitos dos ayuntamientos constitucionais oferecem uma lembrança pungente sobre os horrores da guerra e da opressão que tinham penetrado nas vidas dos mexicanos durante a década de guerra revolucionária. De Miacatlán, o governo municipal informou à Diputación Provincial de México que o sistema das contribuciones militares havia sido extremamente prejudicial e desgastante para a sua população. Eles lamentaram sua condição humilhante e concluíram:

No es posible describir el sumo rigor y violencia que se ha exigido en estos países la contribución militar. Bastará decir que ha habido Indio infeliz que no teniendo para satisfacer el medio, o real que se le exige, se ha visto despojar de sus miserables trapos, y quedar expuesta a la más indecente y vergonzosa desnudez: se ha experimentado también que hostigado un hombre de las muchas amenazas, y crueles tratamientos ha padecido en la cobranza de tales pensiones ha llegado al último de la desesperación y tomado una arma, ha cometido un horroroso suicidio. ${ }^{54}$

Os escritores do Miacatlán presumiram que aqueles nos níveis superiores de governo provavelmente não sabiam sobre tais crueldades.

Em uma reunião de rancheiros nos Montes de Altamajaque, no distrito de Chignahuapa, duzentos rancheros se reuniram como tantos outros em outros lugares, durante julho e agosto de 1820, para discutir a Constituição e o novo sistema de governo. Eles votaram em finalizar a cobrança das contribuciones militares que consideravam não serem mais necessárias. Incapaz de compreender o significado da mudança de atitudes e de comportamento desses homens, o Coronel Manuel de la Concha despachou um partido volante de vinte e cinco dragões, comandados pelo Capitão José Ignacio Zuñiga do Regimento de San Luis, para alertar os pecuaristas sobre os perigos das reuniões clandestinas. Concha insistiu que a discussão de assuntos políticos, como a tributação da milícia, tinha de ter lugar no contexto dos ayuntamientos. Ele interpretou as atividades políticas como um sinal de renovação da

\footnotetext{
${ }^{54}$ Ayuntamiento de Miacatlán aos Presidente y Vocales de la Exma. Diputación de México, 4 de novembro de 1820, AGN: OG. Vol. 455.
} 
revolta e notou que essas mesmas pessoas haviam apoiado o chefe rebelde José Franscisco Osorno, no início da guerra. ${ }^{55}$

Em Puebla, o Brigadeiro Llano percebeu as mesmas reações dos ayuntamientos constitucionales de sua jurisdição provincial. Pequenas cidades de pouco mais de um milhar de residentes elegeram governos municipais e enviaram delegações para Llano, as quais clamaram por um fim imediato dos impostos de milícias. Cada comunidade culpou o sistema monárquico militar por seu estado infeliz e miserável..$^{56} \mathrm{O}$ ViceRei Venadito respondeu para Llano que a questão dos fundos para as milícias locais era problema dele e do intendente da província de Puebla. Llano voltou aos ayuntamientos para propor taxas mais modestas, mas recebeu uma resposta de que nem os ricos nem os pobres pagariam. $\mathrm{O}$ que foi pior, os ayuntamientos alertaram Llano que poderia ser perigoso para o seu governo aumentar a pressão sobre o problema. Algumas cidades não se incomodaram em queixar-se e simplesmente guardaram suas armas na casa do ayuntamiento e demitiram seus milicianos. Desde que Llano reconheceu que os ayuntamientos foram responsáveis pela nomeação de oficiais, recrutamento e pagamento de todos os custos, não havia mais nada que pudesse ser feito. ${ }^{57}$

Nem os comandantes monarquistas, nem os burocratas civis reconheceram que a introdução da Constituição Espanhola lançou o que foi uma revolução pacífica e bastante democrática. Se os comandantes que militarizaram a Nova Espanha para resistir à revolução agora pretendiam manter redes de milícias locais e distritais, eles teriam de lidar com a política e os políticos locais em vez de impor soluções arbitrárias. A Constituição transferiu significantes poderes para o povo, que estava ansioso para exercer os seus direitos em defesa dos seus interesses. Dentro dos ayuntamientos constitucionales e nas comunidades em geral, lideranças locais discutiam sobre o significado dos artigos da Constituição, enquanto aqueles que eram analfabetos ouviam atentamente sua leitura em voz alta. Em Tlaxco, por exemplo, os membros do ayuntamiento debateram o significado do artigo 172, seção A, e artigo 338. Eles concluíram que a tributação exorbitante para apoiar as milícias urbanas monarquistas agora era completamente ilegal. Além disso, se o próprio rei não poderia cobrar contribuciones militares, os constitucionalistas em Tlaxco concluíam que as autoridades

\footnotetext{
${ }_{55}$ Manuel de la Concha a Venadito, Tulancingo, 25 de agosto de 1820, AGN: OG. Vol. 118.

${ }^{56}$ Llano a Venadito, Puebla, no. 566, 28 de julho de1820, AGN: OG. Vol. 325.

${ }^{57}$ Llano a Venadito, Puebla, no. 1050, 11 de setembro de 1820, AGN: OG. Vol. 461.
} 
subordinadas na Nova Espanha certamente não poderiam impor tais impostos. ${ }^{58}$

Outros administradores, como o Subdelegado Francisco de Ortiz em Huejutla, argumentou que, embora as cidades indianas de Taltocan e Yxcatlan tivessem população superior aos 1.000 habitantes necessários para eleger um ayuntamiento constitucional, ele não acreditava que eles poderiam funcionar de uma forma verdadeiramente constitucional. Em sua opinião, eles eram incapazes de compreender até mesmo os princípios mais básicos da Constituição: “...como su absoluta incapacidad para entender aun los mas obvios principios del Nuevo sistema, ya por ser pecado mazorrales sin idioma castellano ni cultura alguna, ya por sur habitud inmemorial de obrar depender en todo sus antiguas superiores." 59

Desde a declaração da Constituição, a maioria dessas pessoas se recusou a reconhecer qualquer autoridade, alguns deixaram suas comunidades, muitos beberam diariamente em excesso, e todos se recusaram a pagar os impostos legítimos, a enviar seus filhos à escola, ou a fazer qualquer trabalho. Como Subdelegado José María Torres de Santa Ana perto da Cidade do México conclui, o povo das cidades subordinadas a ele acreditava "...que la Constitución es alguna patente impresa que los autoriza para violar impunemente las leyes y para no reconocer autoridad alguna." 60

Os debates sobre a tributação da milícia também anteciparam, de um modo geral, em algumas províncias, que a década da revolução tinha acabado e que era a hora de restaurar o comércio, indústria e agricultura. Em San Juan del Río, membros do ayuntamiento elogiaram o retorno da paz no País e insistiram que as supérfluas infantarias urbanas e as companhias de cavalaria precisavam ser dissolvidas. Eles compuseram um argumento legal contra as tributações das milícias com base na interpretação do artigo 321 da Constituição. Uma questão ainda mais urgente era que o fundo de suporte às milícias usado para pagar os milicianos somava mais de 8.000 pesos de dívida. Os credores clamavam por seu dinheiro e o ayuntamiento não tinha ideia de onde poderia encontrar uma soma tão grande. ${ }^{61}$ Enquanto a dívida em San

\footnotetext{
${ }^{58}$ Ayuntamiento de Tlaxco a Concha, 12 de agosto de 1820, AGN: OG. Vol. 118.

${ }^{59}$ Francisco de Ortiz ao Intendente de México, Ramon Gutiérrez del Mazo, Huejutla, 22 de janeiro de 1821, AGN:OG. Vol. 455.

60 José María Torres a Venadito, Santa Ana de México, 23 de novembro de 1820 AGN: OG. Vol. 457.

${ }^{61}$ Ayuntamiento de San Juan del Río a Venadito, 24 de julho de 1820, AGN:OG. Vol. 512.
} 
Juan del Río permaneceu, questões sobre o significado da Constituição em relação às milícias locais culminaram com publicação de uma lei real promulgada em Madrid em 11 de fevereiro de 1820. O Rei proibia a generais, comandantes de divisões e outros oficiais imporem e recolherem os seus próprios impostos das cidades para garantir a subsistência do exército. ${ }^{62}$

Em seu entusiasmo com a Constituição, com as eleições, e para se livrar da tributação militar opressiva, em 1820, muitos novohispanos convenientemente esqueceram que, em algumas regiões, a insurgência não havia terminado. Claramente, o regime do Vice-Rei Venadito e dos veteranos militares precisariam repensar suas abordagens de guerra. Alguns dos melhores comandantes e, certamente, aqueles que melhor sobreviveram ao clima severo das guerras regionais foram os que desenvolveram extensas redes de amistad e raízes entre os militares, civis e setores religiosos. A falha de políticas efetivas retrocedeu ou mesmo encerrou carreiras militares e danificou alguns comandantes que não conseguiram jogar um jogo político efetivo. Bons soldados profissionais e estrategistas militares nem sempre eram os melhores comandantes regionais ou distritais. Durante os anos de guerra, uma nova geração de jovens oficiais surgiu e ganhou experiência. Esses homens reconheciam o lado político do avanço na carreira militar e os caminhos para ascender em importância. Os comandantes aprenderam como exaltar suas vitórias no campo de batalha, publicando relatórios de assaltos contra os combatentes insurgentes na Gazeta de México. Os oficiais trabalharam para construir redes e alianças, baseados nos relacionamentos do tempo de academia, que os conectavam a diferentes líderes sociais, econômicos e religiosos, bem como aos setores populares. $\mathrm{Na}$ verdade, alguns detratores dos comandantes e de Agustín de Iturbide, em particular, queixaram-se que tais homens mantiveram a guerra de acordo com seus próprios interesses de carreira e para manter seus comandos. ${ }^{63}$

Os anos de guerra provocaram uma espécie de aprendizado para os oficiais monárquicos - tanto criollos como peninsulares -, que se tornaram mais tarde generais mexicanos, incluindo Agustín de Iturbide, Antonio López de Santa Anna, Manuel Gómez Pedraza, Pedro Celestino Negrete, Anastasio Bustamante, Alvarez Melchor, José Joaquín de

\footnotetext{
${ }_{62}$ José Dávila a Venadito, 7 de novembro de 1820, AGN: OG. Vol. 266.

${ }^{63}$ Representação assinada por Pedro Somoza ao Consejo de las Indias, 26 de fevereiro de 1817, AGI, Mexico, legajo 1147.
} 
Herrera, Vicente Filisola, entre outros. Embora o presente estudo concentre-se na primeira década da Independência, uma contagem dos altos comandantes do exército mexicano releva que, em 1840, a maioria era de origem monárquica, cuja carreira militar teve início durante a época de Independência. Naturalmente, antigos insurgentes, proeminentes, também subiram ao posto de generais do exército, como Guadalupe Victoria, Nicolás Bravo, Vicente Guerrero, José María y Tornel Mendivel, Juan Alvarez e Melchor Muzquiz. ${ }^{64}$ Quase todos esses políticos militares estabeleceram conexões com grupos civis, e os de maior sucesso dedicaram suas carreiras apenas a política.

\section{A ascensão de Augustin Iturbide}

De todos os comandantes monarquistas a ascenderem a uma posição de proeminência antes de 1821, Augustin de Iturbide talvez tenha sido o mais notável, e, em alguns aspectos, um dos piores, mas também um dos melhores oficiais políticos. Santa Anna teve reviravoltas mais espetaculares em sua carreira, mas viveu mais do que os outros e conseguiu escapar dos pelotões de fuzilamento, que muitos dos seus inimigos esperavam que tivesse encurtado a sua passagem por este mundo. Iturbide nasceu em 27 de setembro de 1783, cresceu em Valladolid (Morelia), como o mimado filho de uma rica família peninsular. Tinha vinte sete anos no início da Revolta Hidalgo e, ao final de seus trinta anos, tornou-se imperador do México. Apesar da pouca idade, no início de sua carreira militar Iturbide surgiu como uma força a ser utilizada pelo exército monarquista. Sua notável ambição, sua lealdade aos amigos e aos soldados, sua boa vontade ao pressionar superiores em favor de suas causas, sua habilidade em criar redes de amigos e apoiadores, sua grande energia e persistência e sua absoluta dedicação ao rei deram a ele especial reconhecimento e atenção. No entanto, a autopromoção de Iturbide foi desprovida de qualquer sentimento de vergonha, e ele transformou uma sequência de vitórias da monarquia no campo de batalha em assunto particular seu.

Em 1812, ainda no início de sua carreira, Iturbide se vangloriava de ter participado de nove ações importantes - todas elas mais gloriosas

\footnotetext{
${ }^{64}$ Alberto M. Carreno, Jefes del Ejército Mexicano en 1847: Biografias de Generales de División y de Brigada y de Coroneles del Ejército Mexicano por fines del año de 1847 (México: Imprenta y Fototipia de la Secretaría de Fomento, 1914). Dos dezoito generaisde-divisão, seis eram de origem insurgente e doze eram ex-realistas. Dos vinte generaisde-brigada, quatro eram de origem insurgente, e dezesseis eram ex- realistas.
} 
do que aquelas identificadas pelas "Reales Ordenanzas Militares" como "distinguidos". ${ }^{65}$ Ele se beneficiou de patronos militares bem sucedidos que cuidaram de sua carreira por anos e que se inclinavam a relevar sua tendência em ser arbitrário e extremamente cruel. Iturbide se tornou o flagelo dos insurgentes nas províncias de Bajío, em Valladolid e nos distritos fronteiriços de Nueva Galicia. Ele foi um homem absolutamente comprometido com sua religião, pela certeza de justiça da sua causa e dos males da revolução. Em uma palavra, Iturbide emergiu como um homem com uma missão clara, guiado por uma visão especial e com uma ambição sem limites. A guerra estabeleceu sua carreira, proveulhe de uma plataforma para ascender à proeminência e elevou-o ao topo do sucesso e poder como imperador do México. Simultaneamente, contudo, Iturbide fez poderosos inimigos em seu caminho ao sucesso. Ele desenvolveu comportamentos arbitrários e práticas corruptas como comandante militar e governador da província de Guanajuato, que teriam terminado a carreira de um indivíduo inferior. Sob alguns aspectos, Iturbide falhou em ir além de seu treinamento como comandante da contra-insurgência. De fato, se ele foi um homem de destino, sempre houve um lado negro a frustrar sua diplomacia, fazendo dele um sanguinário e intolerante agressor de seus inimigos e oponentes. Ele podia ser carismático e encantador com seus amigos e seguidores e, ao mesmo tempo, agir como um imbecil, fanático e idiota. ${ }^{66}$

É interessante que, mesmo enquanto um jovem oficial, Iturbide tenha conhecido tantos dos poderosos comandantes monarquistas e que tenha se utilizado de suas conexões para expandir seu crescente círculo de contatos políticos, amigos e conhecidos. No início de fevereiro, Iturbide iniciou o comando operacional da divisão do Conde de García, uma força mista composta por um batalhão de exército regular do Regimiento de Infantería de La Corona, dois esquadrões provinciais de Dragones de Puebla, o Batallón Misto e a cavalaria Cuerpo de La Frontera de Nuevo Santander. No dia 12 de fevereiro, Iturbide liderou uma força mista de infantaria e cavalaria em uma marcha de 17 horas e meia, durante a qual descansaram somente uma hora e meia para surpreender 0 insurgente Albino García, que, segundo informações, estava no povoado de Amole com 4.000 homens. Atacando as duas e meia da madrugada, os monarquistas conseguiram matar alguns insurgentes e a cavalaria

${ }^{65}$ Relación de los Méritos de Agustín de Iturbide, 31 de agosto de 1812, AGN: OG. Vol. 426.

${ }^{66}$ A controvérsia sobre Iturbide continua desde então. Ver, por exemplo, William Spence Robertson, Iturbide; e Anna, Mexican Empire. 
perseguiu o inimigo por mais de uma légua e meia. Levando em conta a exaustão, após tamanha marcha, Iturbide expressou admiração pela coragem e determinação de seus soldados. Nesta ação, o efeito surpresa foi completo e apenas um monarquista foi ferido. ${ }^{67}$

Durante os anos de 1812 e 1813, Iturbide operou por todo Bajío, geralmente contra pequenos bandos de insurgentes que raramente estavam aptos a fazer frente as mais bem armadas e disciplinadas tropas imperialistas. Com velocidade e marchando grandes distâncias, os monarquistas foram capazes de surpreender forças insurgentes à noite, atacando-as com uma combinação de cavalaria, dragões e infantaria montada. Algumas vezes os rebeldes possuíam poucas e velhas armas de fogo e tentavam sem sucesso fabricar espadas, canhões de madeira e mosquetões - algumas vezes cobrindo a madeira com prata para simular armas feitas de metal. ${ }^{68}$ A dificuldade para os monarquistas foi não poder ocupar todas as cidades e vilas e ainda assim manter unidades operacionais disponíveis para combater os pequenos bandos de insurgentes. Iturbide ordenou que os rebeldes aprisionados após as batalhas fossem executados pelos pelotões de fuzilamento, depois de sofrerem um breve interrogatório. Suas forças atacaram eficientemente os insurgentes pelo uso da velocidade, de emboscadas nas vilas, dividindo forças e se reagrupando nos alvos para dominar as defesas dos insurgentes, e, ainda, por meio de ataques organizados e poder de fogo superior.

De ambos os lados, propaganda e ameaça substituíram qualquer possibilidade de diálogo. Iturbide se comunicou com comitês sob seu controle, solicitando suporte ao governo legítimo. Ele assinalou que os chefes insurgentes atraíam novas adesões por meio de mentiras, calúnias e promessas destinadas a atrair os mais ingênuos. Eles criavam grandes mentiras, como, por exemplo: que Morelos havia entrado no México ou o faria em pouco tempo; que os irmãos Rayón estavam em Querétaro, que José Maria Liceaga e Dr. José Maria Cos haviam ocupado Guanajuato e Irapuato e que Verduzco estava em Valladolid. Eles desmascararam os programas imperialistas de anistia, espelhando rumores de que execuções secretas ocorriam logo após o perdão. Iturbide insistiu que a ameaça insurgente era na verdade bastante limitada. Durante a ausência das forças monarquistas, eles foram capazes de

${ }^{67}$ Iturbide, Diario Militar, 12 de fevereiro de 1812, Iturbide Papers, Library of Congress (doravante LC), Ms. 15338, rolo 1.

${ }^{68}$ Iturbide a García Conde, Hacienda de San Nicolas, 27 de julho de 1812, LC, Ms. 15338, rolo 1 . 
influenciar e controlar a população, o número de rebeldes disponíveis para o serviço militar na maior parte dos distritos de Bajío raramente excedia de 300 a 700 combatentes destreinados e mal equipados. Eles não possuíam mosquetões e os seus poucos canhões primitivos, carregados dois por mula, eram muito leves e pouco precisos para causar danos significativos. Iturbide concluiu: "Yo opino que cien soldados que merecen El nombre de tales puedem caminar para aqui sin peligro de recibir daño..." ${ }^{69}$

Havia também o grave problema da cooperação fraca entre as muitas jurisdições monarquistas. Para escapar das perseguições, os insurgentes cruzavam as fronteiras das jurisdições provinciais. ${ }^{70}$ Operando nas zonas de fronteiras entre Guanajuato, Valladolid e Nueva Galícia, os insurgentes compensavam suas fraquezas crônicas: a falta de disciplina e o armamento inferior. Iturbide reconheceu a necessidade de cooperação entre as forças monarquistas das diversas províncias. Ele visitou Valladolid, onde o Coronel Torquato de Truxillo não era cooperativo, mas ajudou os Capitães Antonio Linhares e Pedro Celestino Negrete, os quais comandaram, sob o Comando do Brigadeiro Cruz, forças próximo à fronteira de Nueva Galícia. Durante esses anos, Iturbide se tornou o maior defensor da cooperação militar e foi mais ativo visitando jurisdições e estabelecendo contato com associados, mais do que qualquer outro comandante monarquista.

Grande energia e dura perseguição às forças insurgentes trouxeram a Iturbide um sucesso que impressionou oficiais veteranos e vice-reis. Suas tropas capturaram e executaram o chefe insurgente Albino García em Celaya, e seus ataques à fortaleza rebelde na Ilha de Liceaga, no lago Cuisio, sobrevieram como algo que os imperialistas acreditavam ser uma fortaleza inacessível. Protegida por um forte muro de pedras, uma paliçada de galhos entrelaçados, e cercada por poços profundos, a guarnição de 200 defensores inicialmente aparentava gozar de alto moral. Enquanto as tropas de Iturbide construíam jangadas e canoas, este iniciou uma guerra psicológica, com o objetivo de espalhar um espírito de "terror pánico" entre os insurgentes. Às duas horas da madrugada, de 9 de setembro, a força de invasão aproximou-se da ilha por diferentes lados com uma frota composta por oito grandes balsas e duas canoas. Os soldados monarquistas gritavam: ";Adelante que ya están nuestros

69 Ibid.

${ }^{70}$ Brian R. Hamnett, "Royalist Counterinsurgency and the Continuity of Rebellion: Guanajuato and Michoacán, 1813-20”, Hispanic American Historical Review 62:1 (fevereiro de 1982), 19-48. 
compañeros dentro! ;Vamos, vamos también nosotros adentro! Muera todo El que no rienda, muera en el momento! ;Viva Fernando VII, Viva España!"'. Os monarquistas carregavam grandes pedras, as quais jogavam na água a fim de causar confusão na mira dos rebeldes, quando estes disparavam seus canhões. ${ }^{71}$ A defesa rebelde entrou em colapso, permitindo, assim, que os monarquistas capturassem e assassinassem muitos, inclusive o comandante veterano rebelde Brigadeiro José Maria Valtierra, os Coronéis Francisco Ruiz e Francisco García e o Tenente Coronel de Artilharia Francisco Valle, conhecido como "El Negro de Habana". Somente alguns nadadores mais fortes evitaram de se afogar e conseguiram fugir para a costa. Mais tarde, Iturbide fuzilou seus prisioneiros, dentre eles o comandante insurgente Juan José Ramirez, e vários oficiais, incluindo Pablo Nelson, conhecido como " $E l$ Angloamericano".

Resultados de guerra como o descrito e suas conexões de apadrinhamento, Iturbide ultrapassou outros oficiais para se tornar Coronel do Regimento de Infantaria de Celaya e, em maio de 1813, Coronel e Comandante Geral de Guanajuato e Bajío. Ele declarou não estar muito feliz em ter de retirar o foco dos assuntos puramente militares para atender as demandas de um importante trabalho administrativo, o qual requeria outras habilidades e tato no trato com a elite da cidade. Ele se queixou a Cruz, referindo que havia se transformado de um comandante de divisão de exército em um comandante geral de mulas. Iturbide sabia ter feito inimigos particularmente dentre aqueles invejosos oficiais que o queriam fora de ação. Ele estava certo de que esses indivíduos celebrariam se ele perdesse um comboio inteiro de prata, e vangloriou-se de que, em sete carregamentos, os rebeldes falharam em roubar uma única mula. ${ }^{72}$

Apesar dos esforços bem sucedidos de Iturbide em ganhar o respeito e a amizade dos oficiais do exército, lhe faltava apoio entre muitos setores da população. Seu comportamento digno de um bandido nas operações de contra-insurgência nos distritos rurais da província de Guanajuato e nas margens das jurisdições vizinhas produziu repercussões negativas entre os poderosos líderes religiosos, hacendados, comerciantes e tropeiros. Os hacendados, tal como o Tenente Coronel Pedro Otero, queixaram-se de que as tropas e os tropeiros do serviço militar invadiram suas terras, derrubaram suas árvores frutíferas e videiras e seus funcionários. Eles

\footnotetext{
${ }^{71}$ Instrucción de lo que los comandantes de balsas y canoas deben executar para el asalto de la Isla Liceaga la noche del 31 de octubre de 1812, LC, Ms. 15338, rolo 1.

${ }^{72}$ Iturbide a Cruz, 4 de outubro de 1813, LC, Ms, 15338, rolo 2.
} 
invadiram sua casa, destruíram seu mobiliário, roubaram suas portas e janelas e até mesmo devastaram seu jardim e as árvores frutíferas. Quando Otero foi registrar queixa por suas perdas, Iturbide o tratou como se ele fosse um traidor ou um insurgente. Disse na frente de Otero que, "el Rey no pagaba nada." Contudo, tendo servido sob Calleja na Batalha de Calderón, no cerco de Cuautla Amilpas, e concedido grandes doações para ajudar os esforços de guerra da Espanha, Otero manifestou indignação e apelou diretamente ao Vice-Rei Calleja para a restituição de suas perdas. Ele foi advertido por outros sobre fazer a reclamação por causa do "enojo vengativo" de Iturbide. ${ }^{73} \mathrm{O}$ vice-rei censurou Iturbide e lhe ordenou a controlar seus ressentimentos pessoais. ${ }^{74}$

Deste ponto em diante, Iturbide esteve sob uma crescente onda de reclamações vindas de Guanajuato, até que Calleja não teve outra alternativa senão ordená-lo à Cidade do México, onde permaneceu sem designação até dezembro de 1820, quando foi enviado para lutar contra os guerrilheiros tenazes da Dirección del Sur. Primeiramente, as queixas eram de que Iturbide tinha tomado o controle sobre o comércio de Guanajuato. ${ }^{75}$ No início de 1816, entretanto, o Dr. Antonio Labarrieta, curador e juíz eclasiástico de Guanajuato, submeteu um detalhado relatório ao vice-rei, que também circulou amplamente, o qual condenava Iturbide por uma variedade de crimes. As acusações incluíam prisão injusta de militares e religiosos e, em especial, o abuso de 180 mulheres de Pénjamo que foram presas sem acusação formal. Outras queixas relacionadas à Iturbide eram o saque e o incêndio de haciendas, que pertenciam ao Conde de Gálvez Pérez, e aos reformados TenentesCoronel Pedro Otero e Francisco Crespo Gil. Se esses crimes não fossem suficientes, Labarrieta alegou que Iturbide, como tantos outros comandantes do exército, monopolizaram o comércio, compraram prata a preços artificialmente baixos e detiveram comboios, a fim de elevar os preços pagos pelos comerciantes. Sob seu comando, Iturbide removeu oficiais veteranos por não auxiliarem seus projetos e ultrajou uma série de ayuntamientos, recusando-se a aceitar as suas indicações de candidatos oficiais. Ele foi arbitrário em sua conduta política, manipulando e rejeitando ordens do governo central. Funcionários civis afirmaram que faltaram disciplina e subordinação nas tropas de Iturbide, apesar da grande quantidade de dinheiro gasto com elas. Por fim, Labarrieta

\footnotetext{
${ }^{73}$ Pedro Otero a Vicerei Calleja, Guanajuato, 12 de agosto de 1813, AGN: OG. Vol. 426.

${ }^{74}$ Calleja a Iturbide, $1^{\circ}$ de setembro de 1813, LC, Ms. 15338 , rolo 4.

${ }^{75}$ Carta anônima de "Un Fiel Servidor de VE" a Félix María de Cayeta, sem data, LC, Ms 15338 , rolo 4 .
} 
declarou que Iturbide enganou o vice-rei sobre o resultado de várias operações militares. ${ }^{76}$

Como seria de esperar, Iturbide respondeu às acusações de Labarrieta com raiva característica e lançando uma ofensiva contra o seu algoz clerical. Ele escreveu longamente, criticando o padre por sua reconhecida habilidade de criar problemas, por seus hábitos corruptos, e por suas opiniões. Iturbide combatia todas as acusações e vários outros escritores das comunidades militares e eclesiásticas enviando longos memoriais, defendendo seu caráter e sua atuação como comandante geral de Guanajuato. Quanto à acusação de prender e colocar as mulheres em prisão domiciliar, Iturbide defendeu sua ação afirmando que Calleja empregou a mesma política em relação às mulheres suspeitas de simpatias insurgentes. Ele destacou que Hidalgo não tinha sido tão gentil quando ele executou prisioneiros em Valladolid e Guanajuato. No entanto, ele ressaltou que não tinha acusado com crimes as mulheres, mas apenas as deteve com o objetivo de atraí-las para o lado monarquista. A maioria das mulheres foi solta sob a condição de residir em comunidades guardadas pelas forças monarquistas. Finalmente, depois de ter refutado as acusações com sua melhor capacidade, Iturbide lamentou que ele tivesse sido transformado de um homem educado e de origens distintas em um "un monstruo de maldad". ${ }^{77}$

Apesar das acusações feitas contra Iturbide serem bastante pequenas e semelhantes às queixas dirigidas contra muitos comandantes de guerra monarquistas, o Vice-Rei Calleja levou o assunto a sério e ordenou a Iturbide a retornar Cidade do México. ${ }^{78}$ Iturbide permaneceu na capital por quatro anos, se transformou, como ele disse, por meio de "uma degradante metarmofose de guerreiro a litigante". Ele estava certo de que seus acusadores representavam a conspiração rebelde "... para arrancar de mis manos el mando del Ejército que los perseguía". ${ }^{79}$ Durante seu exílio na capital, Iturbide reteve o comando do Regimento de Celaya e ele pediu ao vice-rei e ao subinspetor geral, Brigadeiro Pascaul de Linan, para promover uma completa investigação que proclamaria sua inocência. Sua nomeação como Comandante Geral

\footnotetext{
${ }^{76}$ Depoimento de Dr. Antonio Labarrieta, 8 de julho de 1816, LC, Ms 15338, rolo 4. Para um resumo detalhado, ver William S. Robertson, Iturbide of Mexico, 42-47.

${ }^{77}$ Iturbide a Calleja, 14 de agosto de 1816; Iturbide a Apodaca, sem data, 1817; Relatório do Tenente-Coronel Manuel de Yruela, Comandante del Batallón Rural de Salamanca, 21 de setembro de 1816; LC, Ms. 15338, rolo 4.

${ }^{78}$ Calleja a Iturbide, 4 de abril de 1816, AGN:OG, vol. 434.

${ }^{79}$ Instancia de Agustín Iturbide, julho de 1817, AGN: OG. Vol. 502.
} 
Rumbo al de Acapulco, em novembro 1820, desafiou suas habilidades. Os grandes bandos insurgentes de Gordiano Guzmán e Isidro Montes de Oca dominavam a região em torno de Apatzingán, e as forças de Vicente Guerrero e Asencio Pedro eram conhecidas por suas habilidades de luta. O capitão geral de Valladolid, o Brigadeiro Luis Quintanar, esperava a possibilidade de ter de enviar suas forças para ajudar Iturbide. ${ }^{80}$

A transformação de Iturbide de dedicado comandante monarquista a líder político da Independência e promotor do Plano de Iguala não é tão difícil de se compreender. Ele reconheceu que a sua carreira militar recebeu golpes mortais pelo caso de Guanajuato. Com o contexto atual de efervescência política generalizada na Nova Espanha durante 1820 e o quase colapso espontâneo do sistema de milícias que haviam sustentado o exército monarquista, a aceitação de Iturbide ao comando mais difícil veio depois que ele já tinha tomado sua decisão. Como Jaime E. Rodríguez salientou, Iturbide tinha usado seu tempo na capital para desenvolver relações próximas com pessoas importantes. ${ }^{81}$ Que houve uma premeditação parece óbvio, esta envolvia o movimento de oficiais do exército que haviam se alinhado à posição do novo comando de Iturbide, bem antes da declaração do Plano de Iguala. Com o exército monarquista sob pressão, Iturbide ofereceu uma saída para todos que temiam soluções mais radicais, caso falhassem em suas ações. Em 19 de março de 1821, o Brigadeiro José Antonio Echáverri, que é citado na epígrafe do presente ensaio, escreveu de Teloloapan, afirmando que ele havia jurado fidelidade ao Plano de Iguala que havia descrito como "nuestra gran obra". Ele esteve presente com as tropas do Regimento de Infantaria da Coroa, Murcia, Santo Domingo, Tres Villas, Celaya, Escuadrón del la Reina e piquetes de outros batalhões. Eles prometeram a manutenção da religião, desejaram que o rei ou um de seus irmãos viesse ao México, e proclamaram a união de todos os que agora se uniam em liberdade dentro do novo Império. Echáverri explicou que este processo foi essencial “... porque se hallaba en peligro de ser presa de otra nación, y de continuar la guerra destructora que en once años llevamos sin intermisión y acaso muy difícil de concluir sino hubieron adoptado estas medidas". ${ }^{82}$

${ }^{80}$ Luis Quintanar a Venadito, Valladolid, n. 5, 5 de dezembro de 1820, AGN: OG. Vol. 702.

${ }^{81}$ Jaime E. Rodríguez O, "The Transition from Colony to Nation: New Spain, 1820-1821," in Jaime E. Rodríguez O. (org.), Mexico in the Age of Democratic Revolutions, 1750-1850 (Boulder: Lynne Reinner Publishers, 1994), 118-19.

82 José Antonio de Echávarri ao Tenente-Coronel Isidro Marron, Teloloapan, 16 de março de 1821, AGN: OG. Vol. 702. 
O rápido colapso do exército monarquista se seguiu. Da Cidade do México, o Vice-Rei Venadito olhou horrorizado como "el perfido e ingrato" Iturbide levantou a bandeira de uma nova rebelião. A ascensão de Iturbide à imperador marcou a notável recuperação de um homem que havia sido condenado ao quase esquecimento. No entanto, o grande entusiasmo para outras soluções, mais uma vez, ultrapassaria Iturbide e o deixaria de lado. Durante a década de 1820, a direção do México era incerta, ficou claro que facções e ideias concorrentes lutavam por supremacia. Para os oficiais do exército - especialmente antigos monarquistas -, a política e as atividades políticas muitas vezes se tornaram muito mais importantes do que as suas carreiras militares. Contudo, não haveria militarização da sociedade ou da política após a experiência de uma guerra brutal que durou onze anos. Se os militares entrassem para a política, eles agiriam mais como políticos do que como representantes das forças armadas. Ao mesmo tempo, a luta longa e desgastante contra a insurgência deixou para trás muitos oficiais superiores e comandantes mais jovens, como Antonio López de Santa Anna, que iria desempenhar um papel importante durante as primeiras décadas da nova nação. 